\title{
Systems Integration and the Department of Energy's Hydrogen Program
}

Conference Paper NREL/CP-150-41405

March 2007

\section{Preprint}

\author{
M. A. Duffy
}

To be presented at the 2007 International Conference on System of Systems Engineering: SOSE in Service of Energy and Security San Antonio, Texas

April 16-18, 2007 


\section{NOTICE}

The submitted manuscript has been offered by an employee of the Midwest Research Institute (MRI), a contractor of the US Government under Contract No. DE-AC36-99G010337. Accordingly, the US Government and MRI retain a nonexclusive royalty-free license to publish or reproduce the published form of this contribution, or allow others to do so, for US Government purposes.

This report was prepared as an account of work sponsored by an agency of the United States government. Neither the United States government nor any agency thereof, nor any of their employees, makes any warranty, express or implied, or assumes any legal liability or responsibility for the accuracy, completeness, or usefulness of any information, apparatus, product, or process disclosed, or represents that its use would not infringe privately owned rights. Reference herein to any specific commercial product, process, or service by trade name, trademark, manufacturer, or otherwise does not necessarily constitute or imply its endorsement, recommendation, or favoring by the United States government or any agency thereof. The views and opinions of authors expressed herein do not necessarily state or reflect those of the United States government or any agency thereof.

Available electronically at http://www.osti.gov/bridge

Available for a processing fee to U.S. Department of Energy and its contractors, in paper, from:

U.S. Department of Energy

Office of Scientific and Technical Information

P.O. Box 62

Oak Ridge, TN 37831-0062

phone: 865.576 .8401

fax: 865.576 .5728

email: mailto:reports@adonis.osti.gov

Available for sale to the public, in paper, from:

U.S. Department of Commerce

National Technical Information Service

5285 Port Royal Road

Springfield, VA 22161

phone: 800.553 .6847

fax: 703.605.6900

email: orders@ntis.fedworld.gov

online ordering: http://www.ntis.gov/ordering.htm 


\title{
Systems Integration and the
}

\section{Department of Energy's Hydrogen Program}

\author{
Michael Duffy \\ National Renewable Energy Laboratory \\ 1617 Cole Boulevard \\ Golden, CO 80401 \\ michael_duffy@nrel.gov
}

\begin{abstract}
The Department Of Energy (DOE) established the Hydrogen Program in response to a Presidential directive. The role of the Hydrogen Program is not to build the nation's hydrogen infrastructure, but instead to develop and validate technologies that will enable industry to make commercialization decisions that lead to establishing and evolving a national hydrogen infrastructure. To provide a solid foundation for a mission-driven Program consistent with the President's directive, the DOE asked the National Renewable Energy Laboratory to establish a Systems Integration Office (SIO) and develop an Integrated Baseline that could be used to effectively and efficiently manage the Hydrogen Program. The SIO has employed a structured process, based on hierarchical decomposition, to identify, define, and analyze the requirements and tasks needed to satisfy the Hydrogen Program's mission. The result is an on-line integrated baseline (i.e., both technical and programmatic considerations) that ensures that these mission requirements and all aspects of the President's directive are addressed.
\end{abstract}

Keywords: Systems Integration, Integrated Baseline, Hydrogen Program, CORE.

\section{Introduction}

In the early 1970s, concern over the United States' growing dependence on imported petroleum, coupled with concerns about our deteriorating air quality as a result of emissions from combustion of fossil fuels, prompted the Department of Energy (DOE) to begin investigating hydrogen technology. However, it was not until President Bush's 2003 State of the Union address that significant funding became available.

Tonight I am proposing $\$ 1.2$ billion in research funding so that America can lead the world in developing clean, hydrogen-powered automobiles. With a new national commitment our scientists and engineers will overcome obstacles to taking these cars from laboratory to showroom so that the first car driven by a child born today could be powered by hydrogen, and pollution free.[1]
In response to this Presidential directive, the DOE established the Hydrogen Program (Program) with the following mission:

To research, develop, and validate hydrogen production, delivery, storage and fuel cell technologies.[2]

The Program was created to develop and validate technologies that will enable industry to make the commercialization decisions that lead to establishing and evolving a national hydrogen infrastructure based on domestic resources that will reduce the nation's dependence on foreign oil; however, it will be up to industry to build the nation's hydrogen infrastructure. It incorporates the results of past efforts with the direction and guidance of the National Energy Policy,[3] the National Hydrogen Vision, [4] the National Hydrogen Energy Roadmap, [5] the President's Hydrogen Fuel Initiative, ${ }^{[6]}$ the Energy Policy Act of 2005,[7] the Advanced Energy Initiative,[8] the FreedomCAR and Fuel Partnership,[9] and the DOE Strategic Plan.[10] The Program includes activities being conducted by the following DOE program offices: Energy Efficiency and Renewable Energy, Fossil Energy, Nuclear Energy, and Science.

In late 2003 the DOE commissioned the National Academies to review the Program. One significant recommendation was to establish an independent systems integration effort to ensure that the various Program elements (such as production, delivery, and storage) fit together seamlessly. In response to this recommendation the Systems Integration Office (SIO) was established at the National Renewable Energy Laboratory in Golden, CO.

\section{Systems Integration Approach}

Shortly thereafter, top-level management began asking, "what's the Hydrogen Program going to cost and how will it be effectively managed?" Although the President designated $\$ 1.2$ billion for the Program during the period 
fiscal year (FY) 2004 through FY 2008, a defensible budget request also needed to be constructed for the period FY 2009 through FY 2015 - the date that enabling technologies will permit a technology readiness decision to be made and an effective management tool needed to be developed and implemented.

The SIO recommended implementation of a structured process, based on hierarchical decomposition, to identify, define, and analyze the technical tasks needed to satisfy the Hydrogen Program's mission - an Integrated Baseline for defining and managing the Program in accordance with DOE Order 413.3, Program and Project Management for the Acquisition of Capital Assets.[11] An approved Integrated Baseline would allow the Program management team to:

- Establish a standard approach for organizing the various elements of the Program;

- Facilitate the formation of a comprehensive timephased budget based on thorough schedule planning and cost estimating;

- Measure performance against an approved Program baseline

Figure 1 illustrates the SIO's concept for developing such an Integrated Baseline. Beginning with a vision of a future operational hydrogen economy by the year 2040, and recognizing that it would take about 20 years to accomplish once industry began offering significant numbers of hydrogen-powered vehicles approximately five years after a serious commercialization decision was made, a desired level of technological capability to be achieved by the Program by 2015 was established. These 2015 Hydrogen Program targets define the technical baseline that drives the work to be accomplished, the schedule to be met, and the estimated cost - i.e., the programmatic baseline. Together the technical and programmatic baselines comprise the Integrated Baseline and form the basis for a requirementsdriven, mission-oriented Program.

The technical portion of the baseline is the complete reference set of technical data describing the current ("asis") state of technological capability and the desired ("tobe") states at various times in the future. These desired states of technological capability are derived from the vision for an operational hydrogen economy in 2040. In essence, the technical baseline ensures that the right work is being done. It is derived from the national policy objectives and other top-level requirements, and is consistent with an assessment of both existing and potential new technology. It defines where the hydrogen technological capabilities are at any point in time and where they ultimately must be to satisfy the future vision.

In operational terms, the programmatic portion of the baseline ensures that the work is being done right - i.e., the work that must be accomplished to provide the required technological capabilities. The right work will be accomplished according to approved work plans, on time and on budget. The programmatic baseline contains all Hydrogen Program data pertaining to the approved scope of work, cost, and schedule.

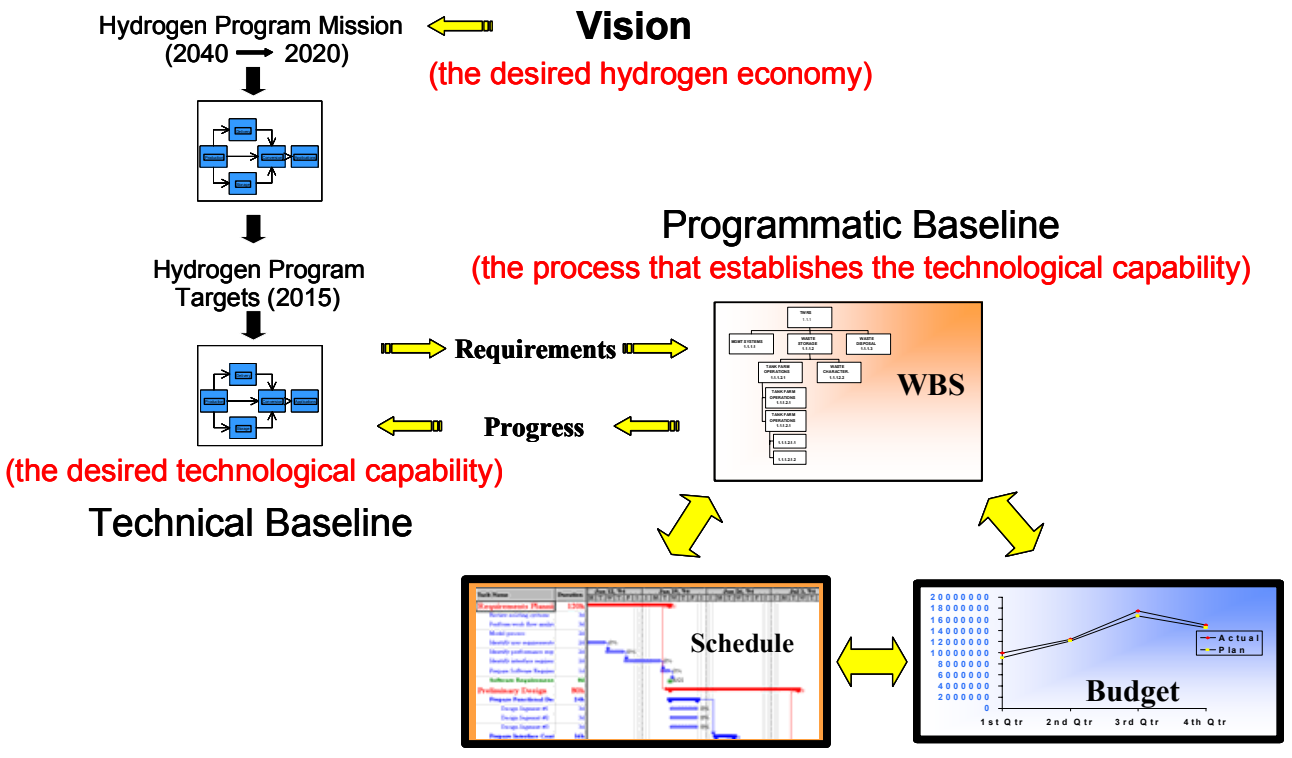

Figure 1. A Requirements-Driven, Mission-Oriented Hydrogen Program 


\subsection{Challenges}

Several significant challenges had to be overcome to develop and implement the Integrated Baseline:

- Ongoing Program. The Hydrogen Program is comprised of nearly 300 ongoing projects spread across different organizations, addressing a variety of technological disciplines, many of which are on the leading edge of technology. Implementing systems integration within an ongoing program is especially challenging due to the existing mindset of managers and staff, other demands on their time, the "not-invented-here" attitude, and steadfast resistance towards systems engineers probing their activities.

- Systems Integration within an R\&D Program. Systems integration has most often been applied to the design, development, production, and maintenance of large, complex acquisition or construction projects. Implementing systems integration within an ongoing R\&D program without delaying or disrupting current efforts represents a significant challenge, especially when the process has not been institutionalized within the organization.
- Inherent Uncertainty in R\&D. Given the inherent uncertainties with regard to achieving desired outcomes from the research and development of new technologies, tailoring the systems integration procedures and tools to the R\&D paradigm and getting them accepted by the Program staff can be challenging.

\subsection{Existing Hydrogen Program Structure}

The Hydrogen Program was already well underway for several years prior to the SIO getting involved and was striving to satisfy the objectives, targets and milestones in the Hydrogen, Fuel Cells \& Infrastructure Technologies Program: Multi-Year Research, Development and Demonstration (MYRD\&D) Plan.[2] Figure 2 shows the "as-is" Program structure encountered by the SIO. Requirements appropriately flowed down from top-level policy directives and documents. Barriers had been identified that represented obstacles in satisfying the requirements and became the basis for creating top-level technical tasks which were determined to be necessary to overcome the obstacles. Unfortunately, these top-level tasks were only decomposed into one more level of detail - hardly enough to allow detailed work descriptions, defensible budget estimates, or sufficient definition of the approximately 300 projects being funded by the Program.

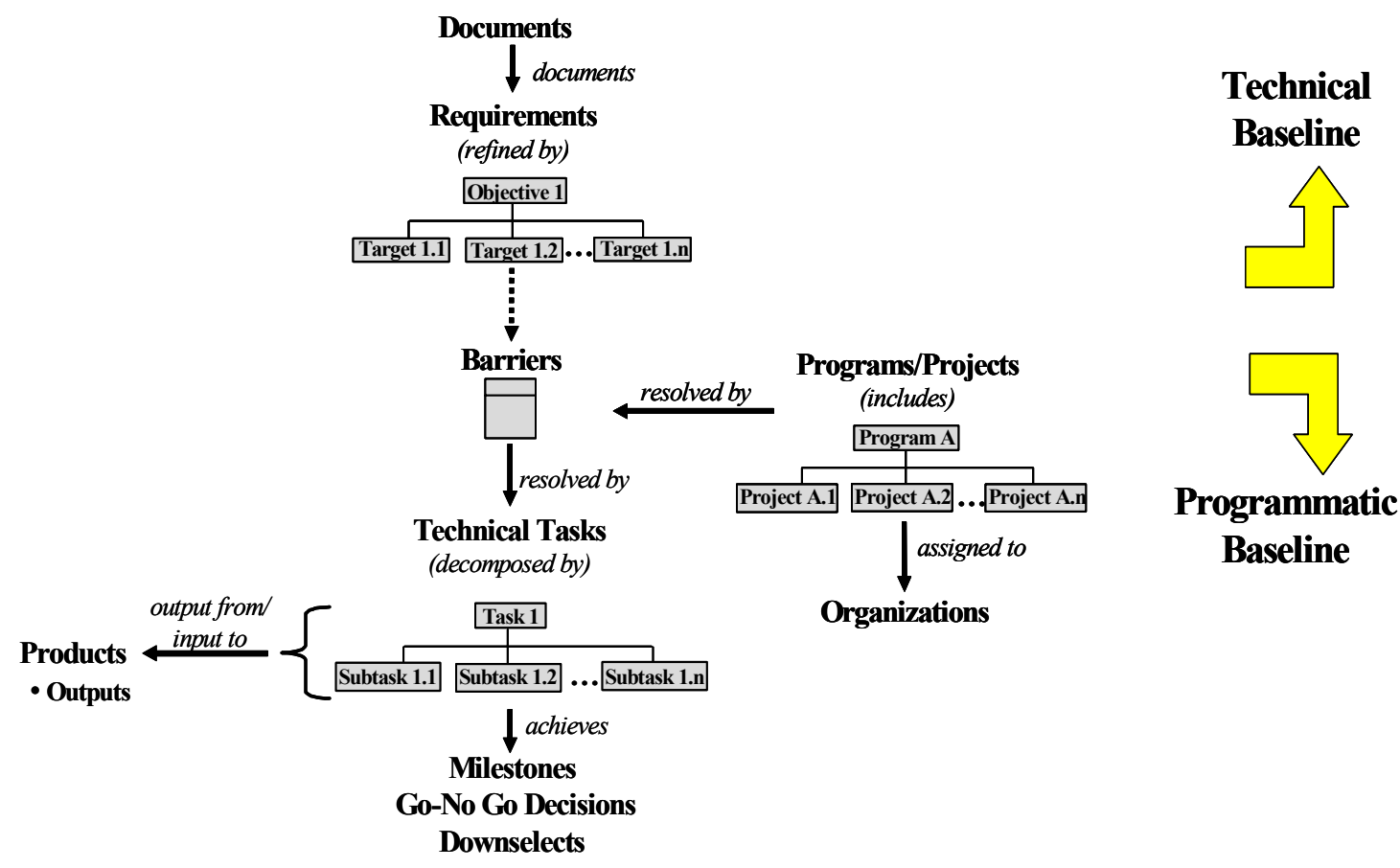

Figure 2. Hydrogen Program Structure prior to Systems Integration 


\subsection{Integrated Baseline Structure}

A top-level work breakdown structure (WBS) had been developed early in the conceptual stage of the Hydrogen Program by dividing it into ten distinct Program Elements: production, delivery, storage, fuel cells, technology validation, safety, codes \& standards, education, systems analysis, and systems integration. However, it quickly became apparent to the SIO that this level of detail was not sufficient to create detailed budget forecasts, nor manage the overall Program effectively. Thus an effort was undertaken to create a more detailed WBS which would be consistent with the size, complexity, and risk of the Program, and the Program Manager's need for more effective control. Specifically, the SIO organized working sessions with Program staff to develop a more detailed work breakdown structure, master schedule, and defensible cost estimates.

Each Program Element manager was instructed to define, schedule and cost the work necessary to meet all their key targets and milestones. Program requirements flowed "top-down", whereas Program budgets were established "bottoms-up". Emphasis was on developing a methodology that could be uniformly applied throughout the Program, so that a consistent set of budget estimates would be constructed across all Program Elements.

Work Breakdown Structure. The WBS is a taskoriented decomposition of the Program and is organized in multiple levels of increasing detail to reflect the complexity of the work scope. Its purpose is to divide the Program into manageable segments of work to facilitate program management, cost estimating and budgeting, schedule management, reporting of cost and schedule performance, and cost and schedule control. A well-designed WBS ensures that all required work is incorporated in the Program and that no unnecessary work is included. The WBS defines the work scope portion of the programmatic baseline.

Scheduling. The first step in scheduling all WBS tasks and sub-tasks was to specify the dates for all key targets and milestones that would be supported by the (sub-) tasks. The start/stop dates for each lowest level sub-task were selected so that the key targets and milestones would be met on time. This became the Program's schedule baseline.

Cost Planning. The purpose of cost planning was to identify the resources needed to accomplish the scope of work and to estimate the associated costs. An unconstrained, bottoms-up approach was used to generate the Program cost estimate by preparing cost estimates for all authorized work as defined at each lowest level activity in the WBS. After the initial cost estimates were prepared, the Program management team met to evaluate and validate each proposed cost, and to reach a consensus on a final cost profile for the Program. Once the cost estimate was approved at all management levels, it became the Program's cost baseline.

Figure 3 shows the new expanded structure for managing the Program after the implementation of the SIO's process.

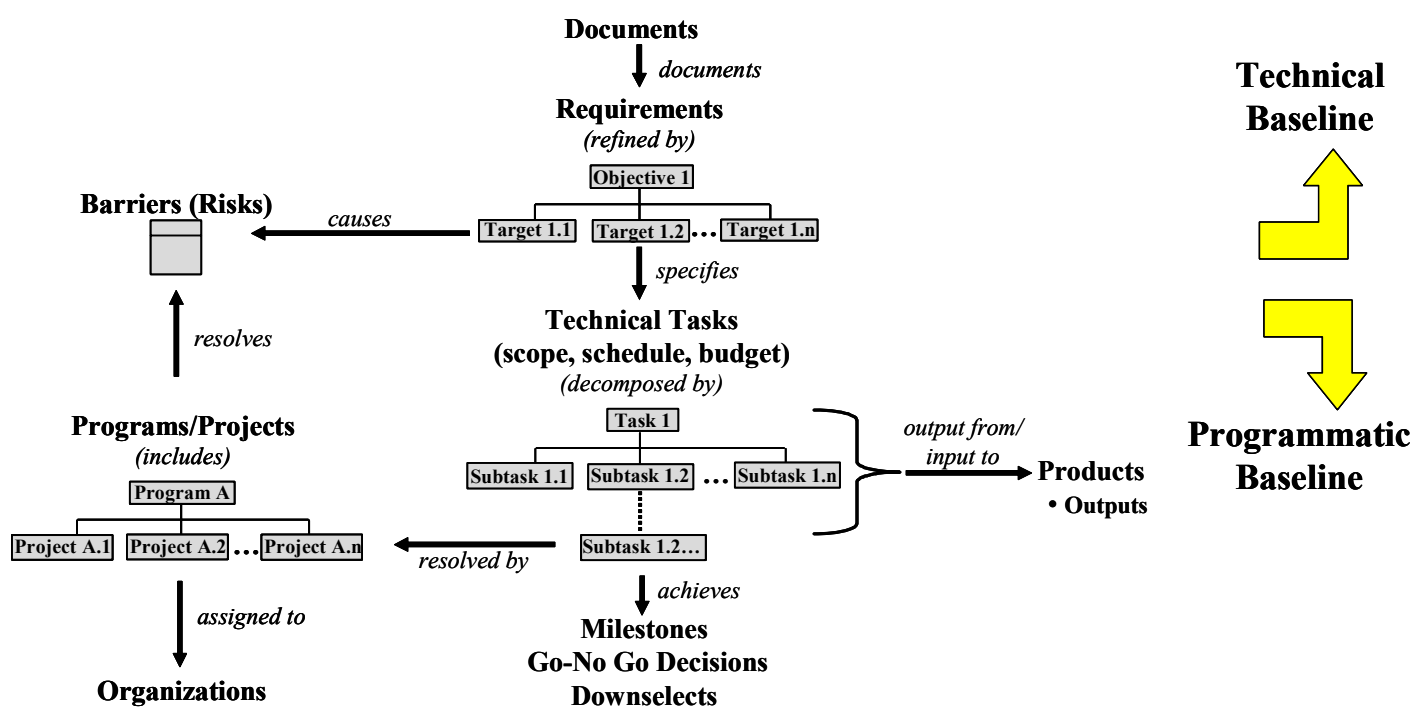

Figure 3. Hydrogen Program Structure after Systems Integration Implementation 
Table 1. Partial Example of a WBS Dictionary

\begin{tabular}{|c|c|c|c|}
\hline $\begin{array}{l}\text { WBS } \\
\text { Element }\end{array}$ & Title & Description & Basis of Estimate \\
\hline \multicolumn{4}{|l|}{ Fuel Cells } \\
\hline \multicolumn{4}{|c|}{ 1. Develop membranes that meet all technical targets } \\
\hline \multicolumn{4}{|c|}{ 1.1 Develop/identify ionomers } \\
\hline 1.1 .1 & $\begin{array}{l}\text { Reduce cost of raw } \\
\text { materials }\end{array}$ & $\begin{array}{l}\text { Develop advanced membrane } \\
\text { materials that are lower cost } \\
\text { than Nafion. }\end{array}$ & $\begin{array}{l}\text { Assumes current level of activity is sufficient to lower } \\
\text { membrane costs to achieve the } 2010 \text { targets. The level } \\
\text { of activity needs to increase as the } 2015 \\
\text { commercialization decision approaches. }\end{array}$ \\
\hline 1.1 .2 & $\begin{array}{l}\text { Improve conductivity } \\
\text { over the entire } \\
\text { temperature and } \\
\text { humidity range }\end{array}$ & $\begin{array}{l}\text { Develop advanced membrane } \\
\text { materials that have improved } \\
\text { performance, i.e. higher } \\
\text { conductivity over the full } \\
\text { operating range of temperature } \\
\text { and humidity. }\end{array}$ & $\begin{array}{l}\text { Assumes that some membrane material candidates that } \\
\text { meet performance over the temperature and humidity } \\
\text { range of } 2015 \text { targets will be needed in } 2012 \text { so that they } \\
\text { can be incorporated into an MEA and stack by } 2015 \text {. } \\
\text { Breakthroughs will be needed to meet the lower } \\
\text { humidification requirements and will require increased } \\
\text { emphasis in } 2009-2012 \text {. }\end{array}$ \\
\hline 1.1 .3 & $\begin{array}{l}\text { Increase mechanical/ } \\
\text { chemical/thermal } \\
\text { stability over the entire } \\
\text { temperature and } \\
\text { humidity range }\end{array}$ & $\begin{array}{l}\text { Develop advanced membrane } \\
\text { materials that have the } \\
\text { chemical and mechanical } \\
\text { strength to operate over the full } \\
\text { operating range of temperature } \\
\text { and humidity. }\end{array}$ & $\begin{array}{l}\text { Assumes that some chemical, mechanical and thermally } \\
\text { stable membrane material candidates with temperature } \\
\text { and humidity range of } 2015 \text { targets will be needed in } \\
2012 \text { so that they can be incorporated into an MEA and } \\
\text { stack by } 2015 \text {. Breakthroughs will be needed and } \\
\text { require increased emphasis in } 2009-2012 \text {. }\end{array}$ \\
\hline
\end{tabular}

Table 2. Partial Example of the Estimated Annual Costs by WBS

\begin{tabular}{|c|c|c|c|c|c|c|c|c|c|c|c|c|c|c|}
\hline \multirow[b]{2}{*}{ Level 0} & \multirow[b]{2}{*}{ Level 1} & \multirow[b]{2}{*}{ Level 2} & \multicolumn{11}{|c|}{ Fiscal Year } & \multirow[b]{2}{*}{ Totals } \\
\hline & & & 2005 & 2006 & 2007 & 2008 & 2009 & 2010 & 2011 & 2012 & 2013 & 2014 & 2015 & \\
\hline & \multicolumn{2}{|c|}{ HFCIT Program } & 124,578 & 121,016 & 187,802 & & & & & & & & & \\
\hline & & Hydrogen Production & 8,680 & 5,898 & 22,550 & & & & & & & & & \\
\hline & & Hydrogen Delivery & 2,500 & 1,000 & 6,600 & & & & & & & & & \\
\hline & & Hydrogen Storage & 22,386 & 26,598 & 35,213 & & & & & & & & & \\
\hline & & Fuel Cells & 55,044 & 34,054 & 57,075 & & & & & & & & & \\
\hline & & \multirow{3}{*}{$\begin{array}{l}\text { Technology Validation } \\
\text { Safety, Codes \& } \\
\text { Standards } \\
\text { Education }\end{array}$} & 26,098 & 33,594 & 39,566 & & & & & & & & & \\
\hline & & & 5,335 & 11,800 & 12,500 & & & & & & & & & \\
\hline & & & 0 & 1,777 & 2,000 & & & & & & & & & \\
\hline & & Systems Analysis & 2,142 & 3,220 & 9,138 & & & & & & & & & \\
\hline & & Systems Integration & 2,393 & 3,075 & 3,162 & & & & & & & & & \\
\hline
\end{tabular}

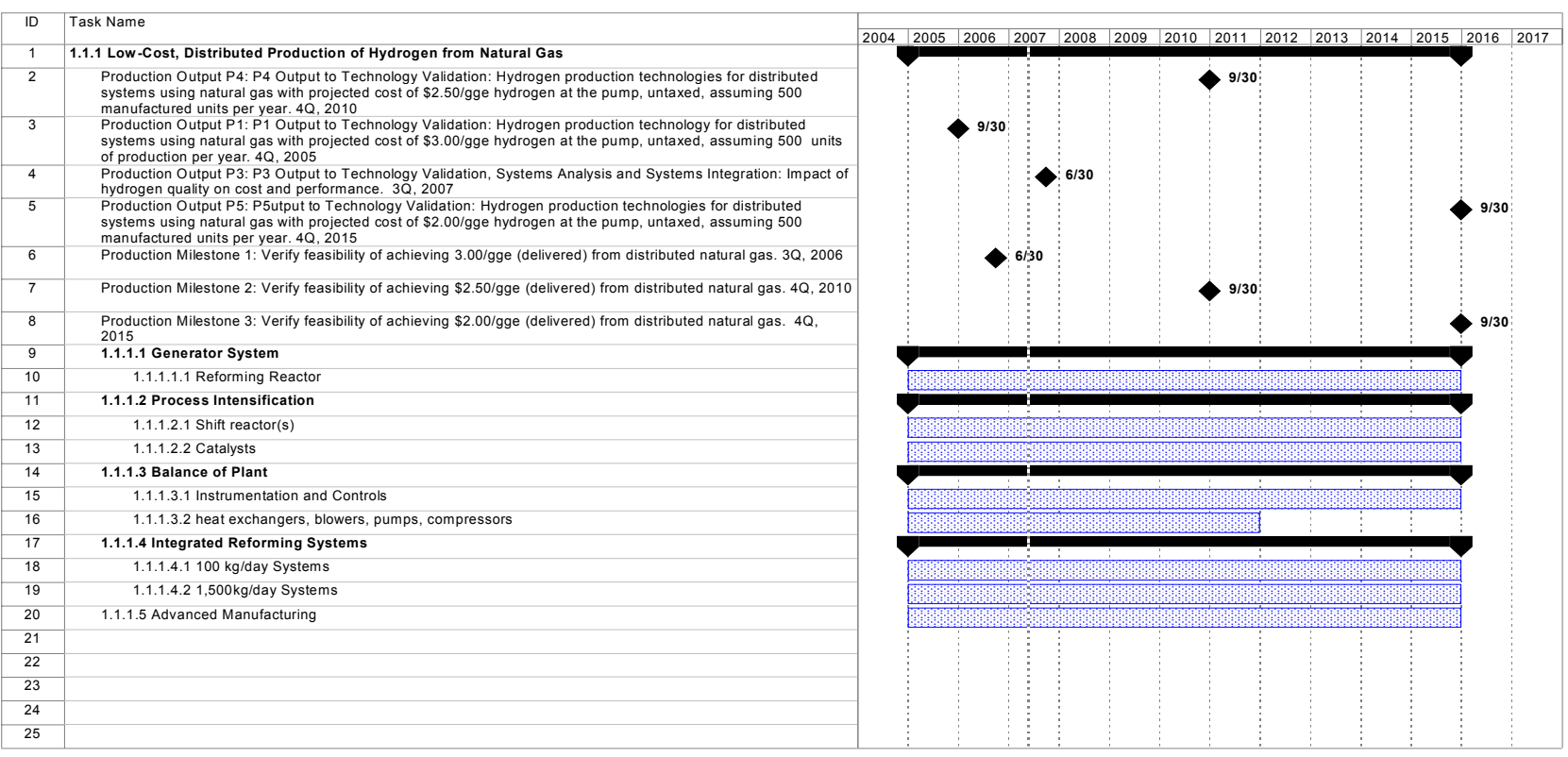

Figure 4. Partial Example of a Gantt Chart 


\subsection{Implementation in CORE}

The SIO's robust approach to program planning ensured that the amount of work to be accomplished, the time allotted to accomplish the Program activities, and the resources required to complete the work scope were evenly balanced. CORE, a computer-assisted systems engineering support tool, was used to organize, coordinate, and document the baseline development effort by capturing the complete set of requirements, tasks, milestones, and projects. The CORE model provides the Hydrogen Program and its Program Element Managers with the necessary requirements traceability to establish a defensible basis for budget estimates and technical decisions; it also produces a variety of output tables and diagrams, including requirement hierarchies, WBS dictionaries, schedules, and annual cost estimates. Outputs from the CORE model can be made available on-line to all Hydrogen Program participants. This will ensure that everyone is working to the same set of requirements at all times. Outputs from the CORE model interact directly with Microsoft Excel and Microsoft Project which is the primary tool for displaying schedules.

WBS Dictionary. CORE can produce WBS Dictionaries (Table 1) consisting of detailed descriptions of each lowest level subtask and the basis-of-estimate for determining its annual cost.

Annual Cost Estimates. CORE can export data from the Integrated Baseline to Microsoft Excel and produce tables containing the annual cost estimates for each Program element, task and subtask through FY 2015. Table 2 is a partial example showing cost data only through FY 2007.

Master Schedule. CORE can export data from the Integrated Baseline to Microsoft Excel and Project to produce Gantt charts (Figure 4) consisting of the start/stop dates for every task and subtask, plus their associated milestones.

\section{Conclusions}

Successful satisfaction of the President's directive and the pace at which the transition to a hydrogen economy must occur has created a complex systems integration challenge for the DOE which is responsible for achieving a level of "technology readiness" that will enable the automobile and energy companies to opt for commercial availability of fuel cell vehicles and hydrogen fuel infrastructure by 2020 . To meet this challenge the Hydrogen Program is being managed in accordance with an approved Integrated Baseline that captures all of the requirements imposed upon the Program, identifies the barriers to satisfying the requirements, the work scope, schedules, and budgets necessary to overcome the barriers, the projects that have been funded to accomplish the work, and the risks that must be managed. Figure 5 illustrates the overall concept.

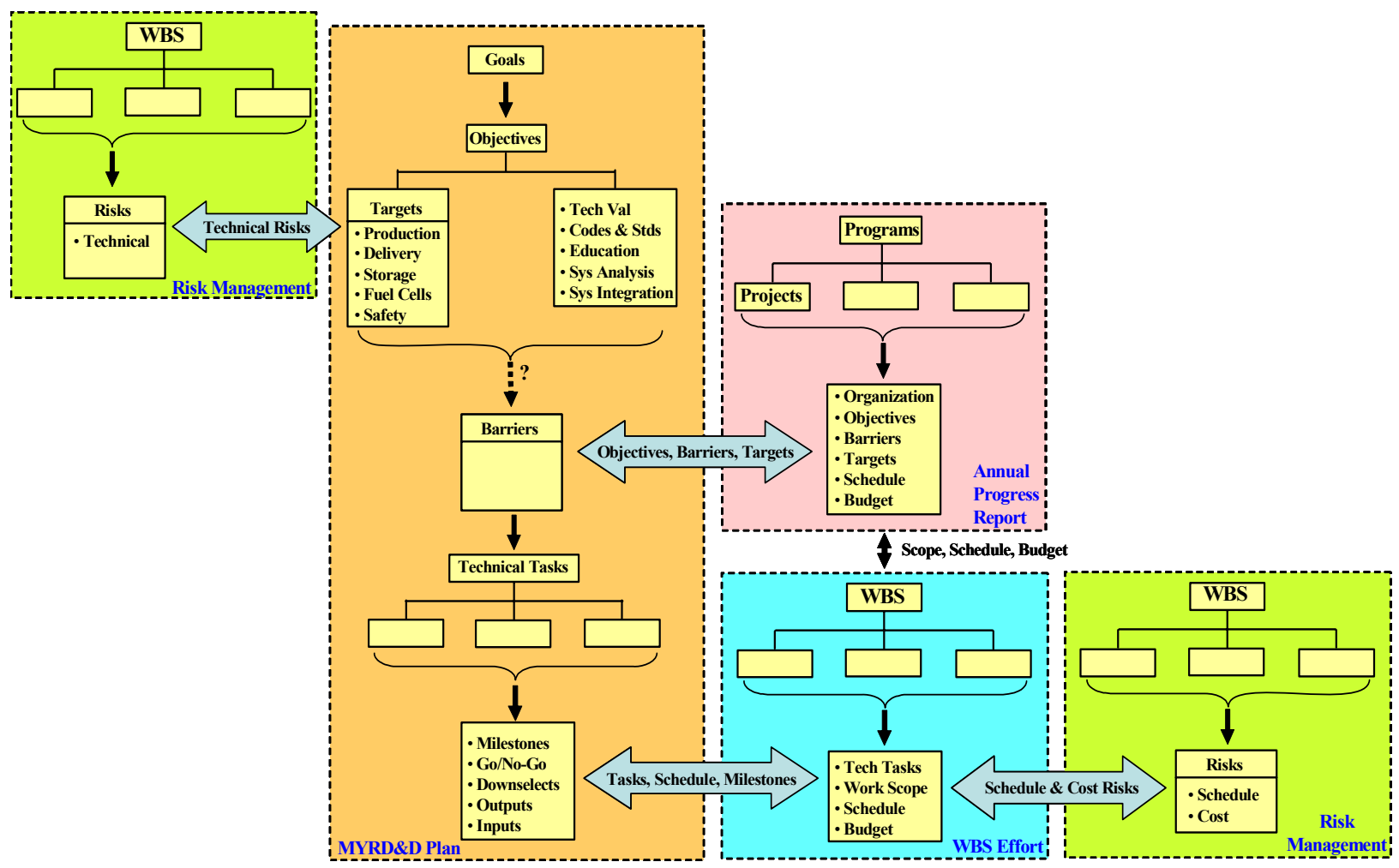

Figure 5. The Integrated Baseline Concept for the Hydrogen Program 


\section{References}

[1] 2003 State of the Union Address. Washington, D.C., The White House, January 28, 2003

[2] Hydrogen, Fuel Cells \& Infrastructure Technologies Program: Multi-Year Research, Development and Demonstration (MYRD\&D) Plan. Washington, D.C.: U.S. Department of Energy, January 2005

[3] National Energy Policy. Report of the National Energy Policy Development Group, May 2001

[4] A National Vision of America's Transition to a Hydrogen Economy - to 2030 and Beyond. Washington, D.C.: U.S. Department of Energy, February 2002

[5] National Hydrogen Energy Roadmap. Washington, D.C.: U.S. Department of Energy, November 2002

[6] President's Hydrogen Fuel Initiative. Washington, D.C., The White House, January 2003

[7] Energy Policy Act of 2005, Pub.L. 109-58. Washington, D.C.: U.S. Congress, August 2005

[8] Advanced Energy Initiative. Washington, D.C., The White House, January 2006

[9] Partnership Plan. FreedomCAR and Fuel Partnership. Washington, D.C.: U.S. Department of Energy, March 2006

[10] U.S. Department of Energy Strategic Plan. Washington, D.C.: U.S. Department of Energy, November 2006

[11] Program and Project Management for the Acquisition of Capital Assets, DOE Order 413.3: Washington, D.C.: U.S. Department of Energy, January 3, 2005 


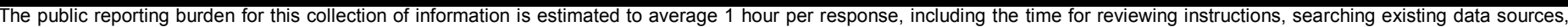

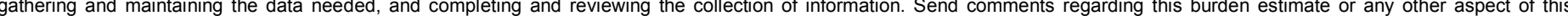

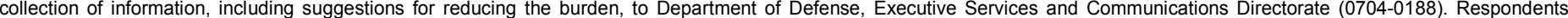

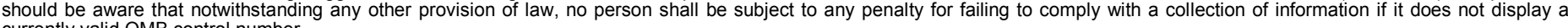
currently valid OMB control number.

PLEASE DO NOT RETURN YOUR FORM TO THE ABOVE ORGANIZATION.

\section{REPORT DATE (DD-MM-YYYY) March 2007 \\ 2. REPORT TYPE Conference Paper}

4. TITLE AND SUBTITLE Systems Integration and the Department of Energy's Hydrogen Program: Preprint
3. DATES COVERED (From - To)

5a. CONTRACT NUMBER

DE-AC36-99-GO10337

5b. GRANT NUMBER

5c. PROGRAM ELEMENT NUMBER

5d. PROJECT NUMBER

NREL/CP-150-41405

5e. TASK NUMBER

HS07.4001

5f. WORK UNIT NUMBER

7. PERFORMING ORGANIZATION NAME(S) AND ADDRESS(ES)

National Renewable Energy Laboratory

1617 Cole Blvd.

8. PERFORMING ORGANIZATION REPORT NUMBER

Golden, CO 80401-3393

NREL/CP-150-41405

9. SPONSORING/MONITORING AGENCY NAME(S) AND ADDRESS(ES)

10. SPONSOR/MONITOR'S ACRONYM(S) NREL

11. SPONSORING/MONITORING AGENCY REPORT NUMBER

\section{DISTRIBUTION AVAILABILITY STATEMENT}

National Technical Information Service

U.S. Department of Commerce

5285 Port Royal Road

Springfield, VA 22161

\section{SUPPLEMENTARY NOTES}

\section{ABSTRACT (Maximum 200 Words)}

This paper discusses how the Systems Integration Office assists the Department of Energy's Hydrogen Program by using an integrated baseline approach to identify, define, and analyze requirements and tasks to achieve program goals.

\section{SUBJECT TERMS}

Systems Integration; Integrated Baseline; Hydrogen Program; CORE

\begin{tabular}{|c|c|c|}
\hline \multicolumn{3}{|c|}{ 16. SECURITY CLASSIFICATION OF: } \\
\hline $\begin{array}{l}\text { a. REPORT } \\
\text { Unclassified }\end{array}$ & $\begin{array}{l}\text { b. ABSTRACT } \\
\text { Unclassified }\end{array}$ & $\begin{array}{l}\text { c. THIS PAGE } \\
\text { Unclassified }\end{array}$ \\
\hline
\end{tabular}

17. LIMITATION
OF ABSTRACT
UL

18. NUMBER
OF PAGES

19a. NAME OF RESPONSIBLE PERSON

19b. TELEPONE NUMBER (Include area code) 